\title{
Developing and Empowering Medium, Small and Medium Enterprises by Digital Platform during This Pandemic Period
}

It has been more than a year since Indonesia,s economy has experienced deflation during the Covid-19 pandemic. Many sectors those affected by deflation include food and beverages, accommodation and others. This deflation phenomenon is caude by many factors. One of the biggest factors is the reduced spending by society or community income groups. This Covid19 pandemic has further eroded people's income and purchasing power. Community's saving are decreasing for consumption needs, especially for those who experienced termination of employment which results in the depletion of household sources of funds

The result of a survey conducted by the Asian Development Bank (April-May 2020) in 4 countres such as Indoneisa, Phillipines, Thailand and Laos which 3.831 MSME respondents explained that the contributions of MSMEs to Gross Domestic Product in the 4 countries was more than $50 \%$. But, the imposition of regional restrictions had a negative impact on MSMEs and some MSMEs were still operating despite a decrease in income moe than $40 \%$. However, the facts show that the problems faced by entrepreneurs are so complex that stimulus and capital assistance only are still inadequate. So far the number of business actors who have entered the digital ecosystem is still relatively small, which means that solutions and innovation are urgently needed for digitizing MSMEs cannot take place for immediately.

The research for this MSME Platform is qualitative research with the aim to find out the development of MSMEs in Indonesia after being affected by this Covid-19 pandemic, a decrease in people's purchasing power and an economic recession. This pandemic outbreak had a negative impact on $84.7 \%$ of MSMEs in our country, average income fell significantly by $53 \%$ and around $72 \%$ OF MSMEs experienced a decline in income of more than $40 \%$. This MSMEs have a very big role in the Indonesian economy.

The contributions of MSMEs to Gross Domestic Product is $61,1 \%$ and also contribute $14 \%$ to exports. The recovery of the ultra-micro and MSME sectors is very urgently needed amidst the pressure of this Covid - 19 pandemic. Micro, Small and Medium Enterprises (MSMEs), small traders are classified as micro business groups with assets of not more than IDR 50 million and a maximum turnover of IDR 300 million per year as written in Law Number 20 of 2008. Every micro, small and medium entrepreneur is required to be able to personalize their digital tools and make themselves open the communities they need. According to Phil Simon (2011), actually platform is not something new in the business world. 
On the oder side, communication and socialization are also needed in an effort to empower MSMEs including solutions to raw material problems and increasing MSME certainty consistently.

Today's consumers are not passively waiting for some information about the desired product but consumers also actively seeking information and event providing comments about the product. MSMEs need to be continuously encouraged so that they can be integrated into the national production system or global supply chain. MSMEs are still far away to reach digital platforms and cannot optimize the opportunities. Ministry of Trade has made up many rules including maximizing trade representatives abroad, strengthening MSMEs competitiveness, providing promotions in a virtual world, exploring the opportunities of business, and many more. But, the MSMEs should learn how to use the digital tools so that the help of the government ends up in a good way. MSME products in the creative field has its own selling value compared to mass manufactured products. 